Article

\title{
Hydrothermal Carbonization of Brewery's Spent Grains for the Production of Solid Biofuels
}

\author{
Mateusz Jackowski ${ }^{1, *}$, Damian Semba ${ }^{1}$, Anna Trusek ${ }^{1}$, Mateusz Wnukowski ${ }^{2}$, \\ Lukasz Niedzwiecki ${ }^{2, * \mathbb{D}}$, Marcin Baranowski ${ }^{2}$, Krystian Krochmalny ${ }^{2}$ and \\ Halina Pawlak-Kruczek ${ }^{2}$ \\ 1 Division of Bioprocess and Biomedical Engineering, Faculty of Chemistry, Wroclaw University of Science \\ and Technology, Norwida 4/6, 50-373 Wrocław, Poland; damian.semba@pwr.edu.pl (D.S.); \\ anna.trusek@pwr.edu.pl (A.T.) \\ 2 Department of Boilers, Combustion and Energy Systems, Faculty of Mechanical and Power Engineering, \\ Wroclaw University of Science and Technology, 50-370 Wrocław, Poland; \\ mateusz.wnukowski@pwr.edu.pl (M.W.); marcin.baranowski@pwr.wroc.pl (M.B.); \\ krystian.krochmalny@pwr.edu.pl (K.K.); halina.pawlak@pwr.edu.pl (H.P.-K.) \\ * Correspondence: mateusz.jackowski@pwr.edu.pl (M.J.); lukasz.niedzwiecki@pwr.edu.pl (L.N.); \\ Tel.: +48-71-320-2283 (M.J.); +48-71-320-2181 (L.N.)
}

Received: 28 December 2018; Accepted: 21 January 2019; Published: 1 February 2019

\begin{abstract}
To make a beer there are four essential ingredients needed: water, malt, hops, and yeast. After brewing process, the main wastes are spent grains. These are often used as additions to fodders in animal husbandry. This study presents preliminary results of an investigation aiming to determine the feasibility of an alternative use of spent grains as a potential source of solid fuel. This source of energy could make breweries partly sustainable in terms of their energy supply. Such an approach may be feasible especially in large scale industrial breweries. This preliminary study presents encouraging results, showing improvements in terms of the fuel properties of the spent grain after its valorization through hydrothermal carbonization. Moreover, qualitative GC-MS analysis also indicates potential feasibility of the liquid byproduct of the hydrothermal carbonization of spent grain for biogas production. Results of proximate, ultimate, and DTG analyses show that hydrothermal carbonization of spent grain could improve its fuel properties and make it an especially suitable feedstock for fast pyrolysis and gasification. Improvement of $\mathrm{HHV}$ is also an improvement in terms of combustion.
\end{abstract}

Keywords: spent grains; beer; malt; hydrothermal carbonization; bioenergy

\section{Introduction}

Beer is one of the oldest drinks known in human history. It is widely known from ancient times. The first time beer was mentioned about 6000 years BC [1]. Moreover, this beverage was brewed all around the world, even in ancient Greece, which is usually associated with wine [2]. Throughout the years the brewing process was developed, and beer became an important branch of the food industry. In 2017, world beer production reached 1.95 billion hectoliters [3]. As the shares of the consumption of beer, wine, and spirits tend to even out in the OECD (the Organization for Economic Co-operation and Development) countries, it is sensible to assume that the aforementioned consumption will not decrease in upcoming years or decades [4]. This high production means that this branch of industry creates a lot of wastes, especially spent grains. These are mainly used as a fodder in the agriculture industry [5]. This byproduct of beer is also used by home brewers to bake cakes. Moreover, there have been studies about adding spent grains to enrich bread. The results showed that such supplementation increased the fibre level and stability of the bread [6]. 
What is the difference between malt and typical barley? Malting is a process in which raw grain is converted into malt. At the beginning of that process, grains are steeped to increase humidity. Aeration of the wet material then begins. These two steps are necessary to start germination of seeds. Sprouting is a key step during formation of malt, because in that step hydrolytic enzymes such as alpha-amylase and beta-amylase are formed. These biocatalysts will be crucial during the mashing process, due to their role in cleaving starch chains into smaller compounds that are fermentable by yeasts. The next step of malting is kilning, the goal of which is to stop germination. In this process, the enzymatic activity of seeds is stopped through drying. At the end, roots are removed. After the described processes, grains are converted into malt [7,8]. Only scarce information has been published so far on the use of spent grain for energy purposes [9]. Sperandio et al. investigated the basic fuel properties of spent grain, and assessed the possibility of using it as feedstock for biochar production [9]. The basic fuel parameters of spent grain were also investigated by Enweremadu et al. [10].

Hydrothermal carbonization (HTC) is a thermal valorization process, typically performed at elevated temperatures (typically 200 to $260{ }^{\circ} \mathrm{C}$ ) in subcritical water, at elevated pressure [11,12]. At temperatures of 200 up to $280^{\circ} \mathrm{C}$, the ionic constant of water is subject to significant increase, and water behaves as a non-polar solvent [13]. The process involves a multitude of concurring reactions yielding multiple different products, especially in the case of complex substances such as different types of biomass [11,12]. Hydrolysis is the first stage of the HTC process. During this stages, biomass is degraded to vast amounts of monomers and oligomers [11], with some intermediates, such as 2-furfural, 5-hydroxymethylofurfural (5-HMF), being subsequently produced [11,14]. Literature mentions that the rate of hydrolysis is diffusion controlled, and therefore is limited by transport phenomena within the fibrous structure of the biomass [15]. Therefore, increase in the temperature enhances the hydrolysis rate [16-18]. Hydrolysis is followed by dehydration and decarboxylation $[11,14,19]$. Dehydration decreases the amount of hydroxyl groups $(\mathrm{OH})$ [11]. Colloidal structures are destroyed, thus decreasing the amount of hydrophilic groups and promoting formation of gases (mainly $\mathrm{CO}_{2}$ ) [12]. Other gases such as $\mathrm{CO}, \mathrm{CH}_{4}$, and $\mathrm{H}_{2}$ (in case of a catalytic process) can also be detected [16,17]. Decrease in the amount of $\mathrm{OH}$ groups also causes a lower $\mathrm{O} / \mathrm{C}$ ratio. Decarboxylation decreases the amount of carboxyl $(\mathrm{COOH})$ and carbonyl $(\mathrm{C}=\mathrm{O})$ groups, also slightly decreasing the $\mathrm{O} / \mathrm{C}$ ratio of the solid product [11]. This is followed by polymerization and aromatization [11,14].

Decrease in the amount of hydroxyl groups is the key aspect in making hydrothermally carbonized biomass more hydrophobic, lowering its equilibrium moisture content [20] and making physical de-watering easier [11]. This has been confirmed not only for biomass, but also for a wide range of low rank coals and peat [20-26]. Moreover, the process of hydrothermal carbonization can increase the grindability of the processed biomass, and enhance the biomass in terms of the composition of inorganic fraction [12,27]. Some studies reported relatively easy pelletizing of hydrochars [28], which was confirmed by Volpe et al., who reported electricity consumption for pelletization of HTC treated olive mill residues of $17 \mathrm{kWh} /$ ton [29], which is roughly half of the typical consumption for wood pellets and a quarter of typical consumption for torrefied wood pellets [30]. This makes hydrothermal carbonization a prospective valorization process for low quality solid biofuels, especially when wet biomass is concerned as a potential feedstock.

Liquid byproducts of HTC are sometimes considered as a potential feedstock for biorefineries [14,31]. Moreover, potential synergy between hydrothermal carbonization and anaerobic digestion is also very appealing [14,32-35]. Wirth and Mumme obtained daily yields of methane of up to $0.25 \mathrm{dm}^{3}$ per $\mathrm{dm}^{3}$ of the HTC liquid [35]. Svensson et al. [32] determined thermal hydrolysis of digestate cake to be an efficient technology for improving methane production and de-waterability in conventional anaerobic digesters, for the cases of sewage sludge and separated food waste. Erdogan et al. [33] determined that the methane production potential for spent HTC liquid, after hydrothermal processing of orange pomace, was between $213.6 \mathrm{~mL}$ and $195.3 \mathrm{~mL}$ of $\mathrm{CH}_{4}$ per $\mathrm{g}_{\mathrm{COD}}$ (where COD-chemical oxygen demand), depending on the process parameters. In the HTC liquid, typical products such as acetic acid, formic acid, lactic acid, glycose, and saccharose were the most abundant, reaching 
concentrations in the order of magnitude of $1 \mathrm{~g} / \mathrm{dm}^{3}$ [33]. HMF and furfural were also detected, with maximum concentrations of 679.7 and $1585.2 \mathrm{mg} / \mathrm{dm}^{3}$ respectively [33]. Moreover, Luz et al. [36] also reported feasibility of the use of the soluble fraction from HTC of spent coffee grounds for anaerobic digestion. Solid biochar could also be used in order to enhance biogas production $[37,38]$. This symbiotic relationship has been recently suggested for hydrochars [39]. Xu et al. reported an increase in the methane content from $57.5 \%$ to $69.8 \%$ after using hydrochars for anaerobic digestion of pig carcass [40]. Luz et al. reported enhanced biomethane potential and synergy that could be an effect of integration of anaerobic digestion with the HTC process [41].

Hydrothermal carbonization typically causes increase of the higher heating value (HHV) of the product (hydrochar) in comparison to the feedstock [11,12,14,31]. It can also cause the material to lose a part of its inorganic fraction, which can be seen either as a decrease in ash content $[12,27,42]$ or the value of ash yield lower than $100 \%$ [12,42]. Hydrothermal carbonization can also increase specific surface area [42] and differential pore volume [43].

The goal of the performed study was to assess the potential feasibility of using spent grain from small scale brewing as a renewable energy source, which could be used to increase the sustainability of such a brewery. The paper aims to assess the fuel properties of spent grain, and valorization of this type of biomass using HTC. Moreover, suitability of the use of liquid byproducts of HTC for the production of biogas is assessed, based on the results of qualitative GC-MS analysis.

\section{Materials and Methods}

Spent grains were obtained as a side product from the brewery located at the premises of the Wroclaw University of Science and Technology (Poland). The beer was made out of $18 \mathrm{~kg}$ of pilsner malt, $2.45 \mathrm{~kg}$ of Munich malt, and $0.85 \mathrm{~kg}$ of dark malt (all malts were purchased from Viking Malt malthouse). Batch size was $100 \mathrm{dm}^{3}$. Mashing regime was $15 \mathrm{~min}$ at a temperature of $63{ }^{\circ} \mathrm{C}$. This temperature is optimal for beta-amylase, which cleaves $\alpha-1,4$-glycosidic bonds, releasing maltose molecules from the non-reducing end of starch chains. The temperature was then raised and kept for $20 \mathrm{~min}$ at $73{ }^{\circ} \mathrm{C}$. At that temperature alpha-amylase is at its highest efficiency and cleaves the $\alpha-1,4$-glycosidic bonds located in the middle of a starch chain. Wort (sugar extract obtained from malt during mashing process) was later boiled with $60 \mathrm{~g}$ of 'marynka' hop pellet (added $60 \mathrm{~min}$ before end of boiling). Then $15 \mathrm{~min}$ before end of boiling another $60 \mathrm{~g}$ of 'marynka' and $30 \mathrm{~g}$ of 'oktawia' hops were added. Additionally, $2 \mathrm{~kg}$ of buckwheat honey was added simultaneously with the second dose of hops. After cooling down the wort, $50 \mathrm{~g}$ of dried yeasts were put into fermenter. After the mashing process, spent grains were separated, and subsequently a sample was taken to perform HTC, in order to minimize the effect of biological activity. Storage in the fridge was thus avoided. Since it is known to have some influence on the composition of beer itself, as shown by MIR (mid-infrared) analyses performed by Pearce et al. [44], immediate use was introduce as a precaution, to avoid any potential bias related to the storage of the spent grain.

The diagram of the experimental setup (Figure 1), shows both the autoclave rig and the hydraulic press that was used for the subsequent dewatering of the sewage sludge. HTC was performed in the autoclave, able to withstand temperatures of $200{ }^{\circ} \mathrm{C}$ and pressures of 150 bar. The autoclave was equipped with a stirring propeller (Figure 1), however, it was not used during the experiments. The autoclave was filled with distilled water and wet spent grain, in order to achieve a water to dry biomass ratio of 10:1, calculated as a mass/mass ratio of the total water (distilled water and moisture in the biomass) to mass of the dry processed feedstock. The size of processed sample was approximately $400 \mathrm{~g}$ of dry mass of feedstock. After adding both biomass and water, the freeboard of the autoclave was purged with nitrogen of technical purity. The autoclave vessel was heated up by a heating mantle with band heaters. The temperature was measured by a K type thermocouple connected to a PLC controller. A setpoint temperature of $200{ }^{\circ} \mathrm{C}$ was chosen as a fairly typical temperature for HTC process, with most of the literature results presented for the range of temperatures between $200{ }^{\circ} \mathrm{C}$ and $260^{\circ} \mathrm{C}[12,27,45]$. Hydrothermal carbonization was performed under the water vapor saturation 
pressure at the specified process temperature. Residence time in the reactor was $150 \mathrm{~min}$. Time measurement started after the autoclave reached setpoint temperature. After $2.5 \mathrm{~h}$, heating mantle was turned off and the setup was left to cool down.

After cooling, the material was drained using a clean colander. A sample was then taken for moisture content test, a separate sub-lot of the sample was taken to test the moisture content (approximately $50 \mathrm{~g}$ ), and a separate sub-lot (approximately $50 \mathrm{~g}$ ) was taken to perform mechanical de-watering. This was performed using a hydraulic press with a custom made piston and filter along with the filter casing. Sample was pressed, using pressure of 60 bar. Pressure was applied for 5 min to let all of the moisture to be drained through the perforated bottom of the filter casing. De-watered material was subsequently taken to test the moisture content.

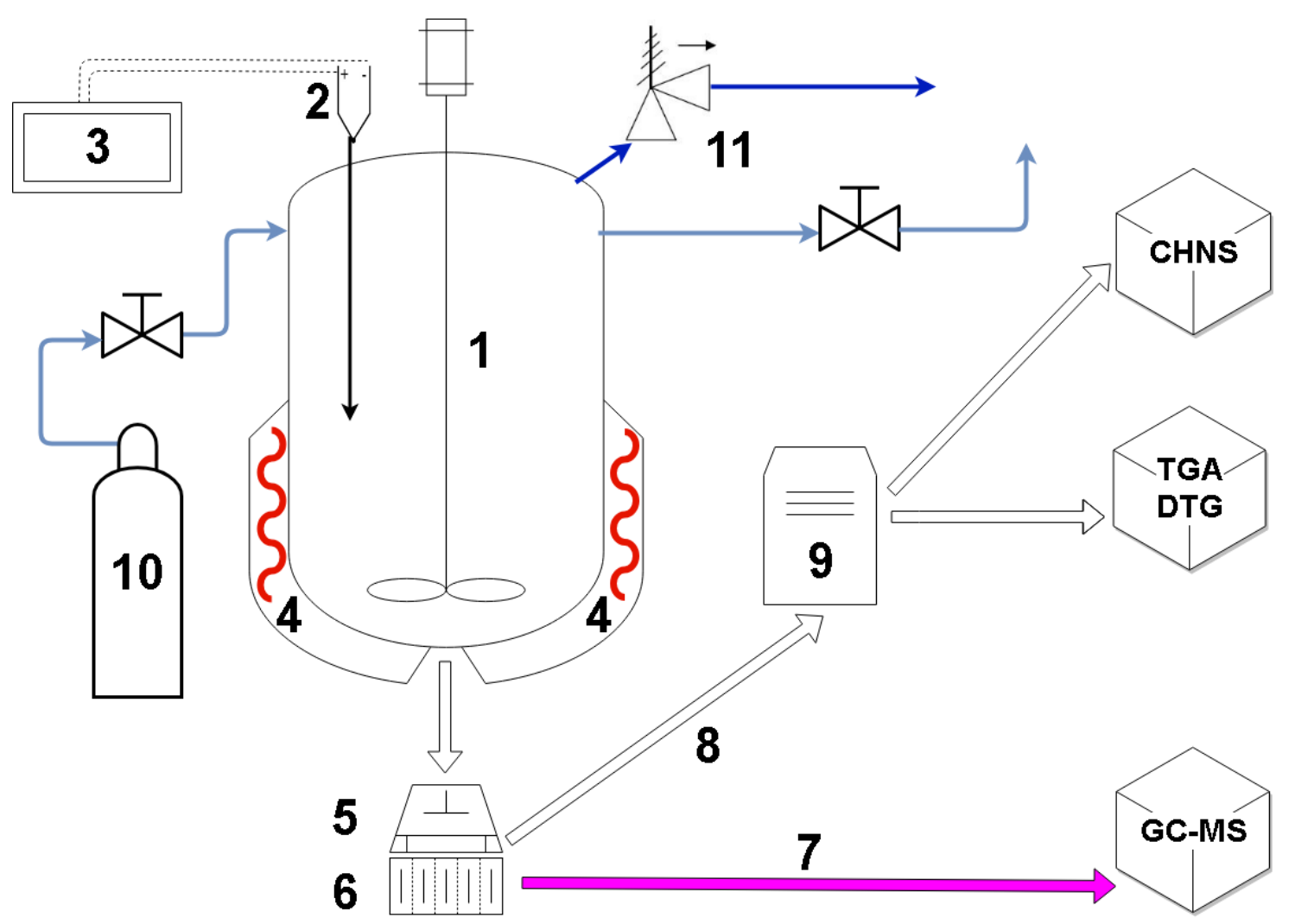

Figure 1. Diagram of the test rig used for hydrothermal carbonization (HTC) of the spent grain. (1)-Autoclave; (2) - type K thermocouple; (3) - PLC controller; (4)-heating mantle, with band heaters; (5)—hydraulic press; (6) —filter; (7)—liquid after mechanical de-watering; (8)—hydrochar after mechanical de-watering; (9)—dryer; (10)—nitrogen for purging; (11)—pressure relief valve.

Samples of both raw and hydrothermally carbonized spent grain were the subject of a TGA/DTG (thermogravimetric analysis/differential thermogravimetric analysis) analysis that was performed using TGA/DTG Pyris Diamond from Perkin Elmer. Nitrogen of $99.999 \%$ purity was used as an inert gas. A two step program was set. During the first step, sample was heated in up to $105^{\circ} \mathrm{C}$ at a heating rate of $200{ }^{\circ} \mathrm{C} / \mathrm{min}$, with a hold period of $5 \mathrm{~min}$ afterwards. During the second step, sample was heated up to $900{ }^{\circ} \mathrm{C}$ at a heating rate of $200^{\circ} \mathrm{C} / \mathrm{min}$. Ultimate analysis was performed using a Perkin Elmer 2400 analyzer, according to the procedure set in the standard EN ISO 16948:2015.

HHV of both feedstock and product was calculated according to Milne's formula [46]:

$$
\mathrm{HHV}=0.341 \cdot \mathrm{C}+1.322 \cdot \mathrm{H}-0.12 \cdot \mathrm{O}-0.12 \cdot \mathrm{N}+0.0686 \cdot \mathrm{S}-0.0153 \cdot \mathrm{A}
$$


where $\mathrm{C}, \mathrm{H}, \mathrm{O}, \mathrm{N}, \mathrm{S}$, and $\mathrm{A}$ are the mass share fractions of carbon, hydrogen, oxygen, nitrogen, sulfur, and ash respectively, in \% mass of dry material. LHV was calculated by deducting latent heat, contributed from both moisture in the material and water created as a product of combustion of the hydrogen in the fuel [46].

In order to assess the severity of the torrefaction process, parameters of mass yield $(\mathrm{Ym})$ and energy yield (Ye) were used as performance indicators, as they are typically used for that purpose [47-50]. Mass yield was assessed using volatile matter content of both feedstock and product, as proposed by Weber et al. [48] for dry torrefaction:

$$
Y_{m}=\frac{1-V M_{\text {feedstock }}}{1-V M_{\text {product }}}
$$

where: $Y_{m}$-mass yield; $V M$-respective volatile matter content of feedstock and product, dry basis, $\%_{\mathrm{db}}$.

A well-established formula was used for calculation of the energy yield [49,51,52]:

$$
Y_{e}=Y_{m} \cdot \frac{H H V_{\text {product }}}{H H V_{\text {feedstock }}}
$$

where: $Y_{e}$ —energy yield; $H H V$ — respective higher heating value of feedstock and product, MJ $/ \mathrm{kg}$.

In order to assess how much of the inorganic substance remained in the solid product, ash yield value was used, as suggested by Wnukowski et al. [27] and Mościcki et al. [12]:

$$
Y_{a}=Y_{m} \cdot \frac{A_{\text {product }}}{A_{\text {feedstock }}}
$$

where: $Y_{a}$ —ash yield; $A$-respective ash content of feedstock and product, dry basis, $\% \mathrm{db}$.

Sample of the liquid by-products of HTC was taken after draining and subsequently analyzed using GC-MS (gas chromatography-mass spectrometry) that consisted of the Agilent 7820-A chromatograph (manufactory, Agilent Technologies, Palo Alto, CA, USA) and the Agilent 5977B MSD spectrometer (Agilent Technologies, Palo Alto, CA, USA). In the chromatograph the Stabilwax-DA column (Restek, Benner Circle, Bellefonte, PA, USA) was used. Helium was used as a carrier gas $(1.5 \mathrm{~mL} / \mathrm{min})$. Heating program was set to achieve $50^{\circ} \mathrm{C}$ in $5 \mathrm{~min}$, subsequently heat up the column with a ramp of $10^{\circ} \mathrm{C} / \mathrm{min}$ until the temperature of $200^{\circ} \mathrm{C}$ was reached, and hold for another $20 \mathrm{~min}$. The data obtained with GC-MS was analyzed using the base peak chromatograms (BPC). The sample was analyzed three times, and the average values of the relative peak areas of the detected compounds, are presented in this study.

\section{Results}

During the brewing process, $100 \mathrm{dm}^{3}$ of wort was achieved with a sugar level of $12.1 \mathrm{BLG}$. This result shows that during extraction, $12.1 \mathrm{~kg}$ of fermentable sugars (mainly maltose) was removed from the grains. After one month of fermentation, the beer was ready with an alcohol content $5.09 \%$ of volume. The achieved product represents proper organoleptic characteristics.

Results of proximate and ultimate analysis of both feedstock and product are present in Table 1. Basic parameters of the process, along with basic descriptors used for its characterization, are presented in Table 2. Results of mechanical de-watering are presented in Table 3. Results of the TGA/DTG analysis, which prove better suitability of hydrochars for fast pyrolysis in comparison to the raw, dry equivalent, are presented on Figure 2. 
Table 1. Proximate and ultimate analysis of raw and hydrothermally carbonized spent.

\begin{tabular}{|c|c|c|c|c|c|c|}
\hline Test & Symbol & Raw & $\begin{array}{c}\operatorname{Raw}^{4} \text { (Data } \\
\text { from [10]) }\end{array}$ & After HTC & Unit & Standard Procedure \\
\hline Moisture content ${ }^{1}$ & $\mathrm{MC}$ & 77.27 & - & 64.15 & $\%$ & EN ISO 18134-2:2015 \\
\hline Volatile matter content & $V^{d}{ }^{d}$ & 71.20 & - & 64.42 & $\%$ & EN 15148:2009 \\
\hline Ash content & $A^{d}$ & 4.30 & 4.46 & 1.91 & $\%$ & EN ISO 1822:2015 \\
\hline Higher heating value ${ }^{2}$ & $\mathrm{HHV}$ & 20,628 & 19,515 & 26,455 & $\mathrm{~kJ} / \mathrm{kg}$ & EN 14918:2009 \\
\hline Lower heating value 3 & LHV & 2412 & - & 7281 & $\mathrm{~kJ} / \mathrm{kg}$ & EN 14918:2009 \\
\hline Carbon content & $C^{d}$ & 47.18 & 48.36 & 58.57 & $\%$ & EN ISO 16948:2015 \\
\hline Hydrogen content & $\mathrm{H}^{\mathrm{d}}$ & 8.20 & 6.02 & 8.29 & $\%$ & EN ISO 16948:2015 \\
\hline Nitrogen content & $\mathrm{N}^{\mathrm{d}}$ & 3.32 & 4.11 & 3.75 & $\%$ & EN ISO 16948:2015 \\
\hline Sulfur content & $S^{d}$ & 0.26 & 0.32 & 0.24 & $\%$ & EN ISO 16994:2016 \\
\hline Oxygen content & $\mathrm{O}^{\mathrm{d}}$ & 41.04 & 36.73 & 29.15 & $\%$ & EN ISO 16993:2015 \\
\hline Oxygen to carbon ratio & $\mathrm{O} / \mathrm{C}$ & 0.65 & - & 0.37 & $\mathrm{~mol} / \mathrm{mol}$ & - \\
\hline Hydrogen to carbon ratio & $\mathrm{H} / \mathrm{C}$ & 2.07 & - & 1.68 & $\mathrm{~mol} / \mathrm{mol}$ & - \\
\hline Oxygen to hydrogen ratio & $\mathrm{O} / \mathrm{H}$ & 0.32 & - & 0.22 & $\mathrm{~mol} / \mathrm{mol}$ & - \\
\hline
\end{tabular}

${ }^{1}$ Wet basis, after mechanical dewatering using hydraulic press; ${ }^{2}$ Calculated using Milne's formula [46]; ${ }^{3}$ Calculated using formula used for Phyliss 2 database [46]; ${ }^{4}$ Barley-Sorghum spent grain; ${ }^{\mathrm{d}}$ Dry basis.

Table 2. Characterization of the HTC process.

\begin{tabular}{cccc}
\hline Parameter & Symbol & Value & Unit \\
\hline Temperature & $\mathrm{T}_{\mathrm{HTC}}$ & 200 & ${ }^{\circ} \mathrm{C}$ \\
Residence time & $\mathrm{t}_{\mathrm{HTC}}$ & 150 & $\mathrm{~min}$ \\
Water: biomass ratio & $\mathrm{W}: \mathrm{B}$ & $10: 1$ & - \\
Mass yield & $\mathrm{Y}_{\mathrm{m}}$ & 0.809 & - \\
Energy yield & $\mathrm{Y}_{\mathrm{e}}$ & $\sim 1$ & - \\
Ash yield & $\mathrm{Y}_{\mathrm{a}}$ & 0.360 & - \\
\hline
\end{tabular}

Table 3. Mechanical de-watering of the spent grain after HTC results.

\begin{tabular}{ccc}
\hline Sample & Moisture Content ${ }^{\mathbf{1}}$ & Unit \\
\hline Raw spent grain & 77.52 & $\%$ \\
Spent grain after HTC and dripping & 84.48 & $\%$ \\
Carbonized spent grain after & 64.15 & $\%$ \\
mechanical dewatering & & \\
\hline
\end{tabular}

1 Wet basis, after mechanical de-watering using hydraulic press, test performed in compliance with EN ISO 18134-2:2015.

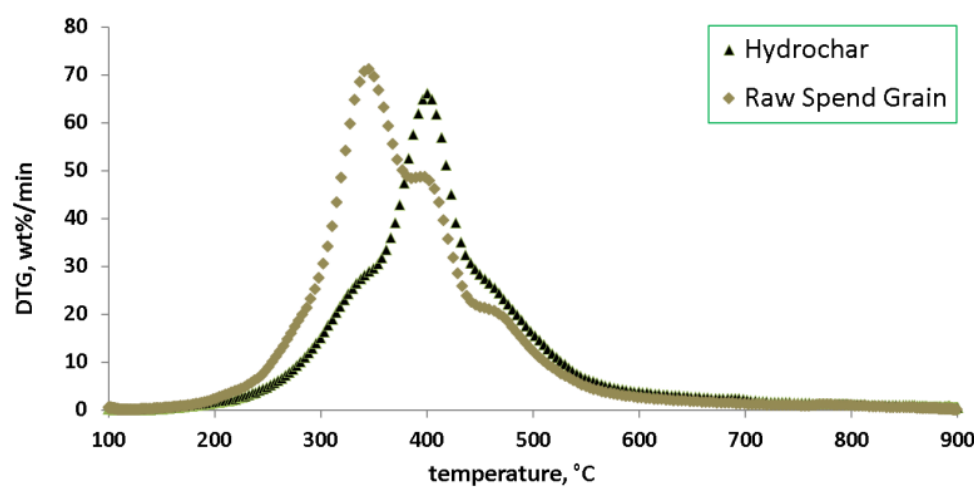

Figure 2. DTG diagram of raw spent grain and corresponding hydrochar.

Results of the qualitative GC-MS analysis of the liquid byproduct, drained after hydrothermal carbonization, are presented in Table 4. Compounds in Table 4 are arranged according to their average masses, as found in the official online database of the Royal Society of Chemical Engineers [53]. Compounds were identified using the software and database delivered by the supplier of the GC-MS 
device (Agilent). Only compounds with a probability higher than $90 \%$ were taken into the account when more than one compound was detected for a specific peak. Relative area of each individual peak, presented in Table 4, is calculated with respect to the total area of all peaks, excluding water.

Table 4. Results of the qualitative gas chromatography-mass spectrometry (GC-MS) analysiscompounds detected in the HTC liquid, after de-watering using hydraulic press (IUPAC names from official online database of Royal Society of Chemistry [53]).

\begin{tabular}{|c|c|c|c|c|}
\hline \multirow[t]{2}{*}{ Compound } & \multirow[t]{2}{*}{ Form } & \multirow[t]{2}{*}{ Avg. Mass } & \multicolumn{2}{|c|}{ Relative Area of the Peak ${ }^{1}$} \\
\hline & & & Relative Area & $\mathrm{SD}^{2}$ \\
\hline IUPAC name & & $\mathrm{Da}$ & $\%$ & $\%$ \\
\hline Methanol & $\mathrm{CH}_{4} \mathrm{O}$ & 32.042 & 0.39 & 0.02 \\
\hline Formic acid & $\mathrm{CH}_{2} \mathrm{O}_{2}$ & 46.025 & 0.60 & 0.11 \\
\hline Ethanol & $\mathrm{C}_{2} \mathrm{H}_{6} \mathrm{O}$ & 46.068 & 2.73 & 0.12 \\
\hline Acetone & $\mathrm{C}_{3} \mathrm{H}_{6} \mathrm{O}$ & 58.079 & 1.30 & 0.53 \\
\hline Acetic acid & $\mathrm{C}_{2} \mathrm{H}_{4} \mathrm{O}_{2}$ & 60.052 & 16.00 & 0.24 \\
\hline 1-Hydroxyacetone & $\mathrm{C}_{3} \mathrm{H}_{6} \mathrm{O}_{2}$ & 74.078 & 4.99 & 0.04 \\
\hline 1,2-Propanediol ${ }^{3}$ & $\mathrm{C}_{3} \mathrm{H}_{8} \mathrm{O}_{2}$ & 76.094 & 0.41 & 0.04 \\
\hline 2-Pyrrolidinone & $\mathrm{C}_{4} \mathrm{H}_{7} \mathrm{NO}$ & 85.104 & 0.23 & 0.01 \\
\hline 3-Hydroxybutan-2-one & $\mathrm{C}_{4} \mathrm{H}_{8} \mathrm{O}_{2}$ & 88.105 & 1.17 & 0.01 \\
\hline 1-Hydroxy-2-butanone & $\mathrm{C}_{4} \mathrm{H}_{8} \mathrm{O}_{2}$ & 88.105 & 0.04 & 0.01 \\
\hline (2S)-2-Hydroxypropanoic acid ${ }^{4}$ & $\mathrm{C}_{3} \mathrm{H}_{6} \mathrm{O}_{3}$ & 90.078 & 25.18 & 0.48 \\
\hline 2,3-Butanediol ${ }^{3}$ & $\mathrm{C}_{4} \mathrm{H}_{10} \mathrm{O}$ & 90.121 & 17.48 & 0.19 \\
\hline 1,3-Propanediol ${ }^{5}$ & $\mathrm{C}_{3} \mathrm{H}_{8} \mathrm{O}_{3}$ & 92.094 & 4.95 & 0.09 \\
\hline 3-Pyridinol & $\mathrm{C}_{5} \mathrm{H}_{5} \mathrm{NO}$ & 95.099 & 17.90 & 0.15 \\
\hline 2-Furaldehyde & $\mathrm{C}_{5} \mathrm{H}_{4} \mathrm{O}_{2}$ & 96.084 & 1.05 & 0.02 \\
\hline 6-Methyl-3-pyridinol ${ }^{3}$ & $\mathrm{C}_{6} \mathrm{H}_{7} \mathrm{NO}$ & 109.126 & 2.88 & 0.06 \\
\hline 1-(2-Furyl)ethanone & $\mathrm{C}_{6} \mathrm{H}_{6} \mathrm{O}_{2}$ & 110.111 & 0.34 & 0.03 \\
\hline 1,2-Cyclopentanedione, 3 -methyl ${ }^{3}$ & $\mathrm{C}_{6} \mathrm{H}_{8} \mathrm{O}_{2}$ & 112.127 & 0.30 & 0.01 \\
\hline 5-(Hydroxymethyl)-2(3H)-furanone & $\mathrm{C}_{5} \mathrm{H}_{6} \mathrm{O}_{3}$ & 114.099 & 0.36 & 0.02 \\
\hline 4-Oxopentanoic acid & $\mathrm{C}_{5} \mathrm{H}_{8} \mathrm{O}_{3}$ & 116.115 & 1.42 & 0.08 \\
\hline
\end{tabular}

${ }_{1}^{1}$ Relative to the total area of all identified peaks; ${ }^{2}$ standard deviation, based on a sample (STDEV.S function in Excel); ${ }^{3}$ or one of its isomers; ${ }^{4}$ L-lactic Acid according to IUPAC nomenclature; ${ }^{5}$ glycerin according to IUPAC nomenclature

\section{Discussion}

Obtained results are in general consistent with the general trends presented in the literature. Moisture content of the raw spent grain $(77.52 \%$-Table 3$)$ was similar to the value obtained by Sperandio et al. (72.88\%) [9]. Results of the proximate and ultimate analysis were close to those obtained by Enweremadu et al. (see Table 1) [10]. Hydrothermal carbonization of the spent grain resulted in increased carbon content of the material (Table 1). Volatile content decreased, whereas HHV increased (Table 1). This is definitely an improvement of the fuel properties. Overall, HTC treatment made spent grain much more similar to hard coal, as the process achieved an HHV of approximately $26.5 \mathrm{MJ} / \mathrm{kg}$, volatile matter content of approximately $64.4 \%$, and carbon content of approximately $58.6 \%$. Moreover, the HTC process allowed further mechanical de-watering (Table 2), thus resulting in a substantial increase in LHV of the produced fuel (Table 1). Although both fuels can be classified as low rank fuels based on their LHV, the difference in LHV shows potentially significant energy savings during subsequent drying, which would be a next step in fuel production. Carbonization was confirmed by both an increase in the carbon content (Table 1) and a decrease of the $\mathrm{O} / \mathrm{C}$ molar ratio (Table 1). Taking $\mathrm{H} / \mathrm{C}$ and $\mathrm{O} / \mathrm{H}$ ratio into the account (Table 1), it can be concluded that the HTC process mainly caused removal of the oxygen from the fuel. This is important in terms of potential use of the valorized fuel as a feedstock for fast pyrolysis [54,55] and gasification [56]. Increase of the HHV and LHV is most definitely an advantage when combustion is considered.

Results of the DTG analysis present some interesting findings (Figure 2). The peak of the differential curve was slightly higher $(71.3 \% / \mathrm{min})$ for raw spent grain, whereas the value obtained for hydrochar $(66.1 \% / \mathrm{min})$ was only slightly lower. However, obtained peaks showed improvements 
where fast pyrolysis is concerned, as the temperature corresponding to the peak was much more favorable for the hydrochar $\left(400.3^{\circ} \mathrm{C}\right)$, in comparison to the feedstock $\left(345.5^{\circ} \mathrm{C}\right)$. Moreover, shoulders of the DTG peak for hydrothermally treated spent grain decreased in comparison to the DTG curve for the raw feedstock. Taking into the account the aforementioned decrease of the $\mathrm{O} / \mathrm{C}$ ratio, it seems that HTC treatment could be an interesting option to consider as a pre-treatment of spent grain for subsequent fast pyrolysis.

It should not be overlooked that HTC treatment also improved fuel parameters of the spent grain by lowering the ash content. Observed ash yield, significantly lower than 1.0 (Table 2), is in good agreement with the results obtained by other studies [12,27,42].

In terms of the assessment of the process it seems plausible to state that HTC seems to be a suitable process for valorization of the spent grain for energy purposes. Mass yield was reasonably good and energy yield was excellent, as most of the chemical energy of the feedstock remained in the product. It should not be overlooked that the loss of part of the mineral content (ash content of 4.3 for the feedstock changed to 1.9 for the product) most certainly introduced some additional bias in terms of the mass yield calculation. However, it was still far more accurate than ash tracer method would be in the same circumstances, as anticipated by Weber et al. [48]. Direct method was impractical in this case, due to the geometry of the inner side of the autoclave vessel, which made complete removal of material difficult. Despite the additional uncertainty mentioned above, it could still be reasonably expected that the energy yield was reasonably close to 1.0, which is encouraging. More work is needed in terms of the optimization of the process, as the residence time is the key aspect in determination of the productivity of such reactors.

Qualitative GC-MS analysis of the liquid byproduct of HTC (Table 4) revealed that typical products of hydrothermal carbonization of biomass, such as 1-lactic acid, acetic acid, and formic acid were accompanied by significant amounts of 3-pyridinol and 2,3-butanediol, along with glycerin and some other compounds. Some of these compounds can be found also in beers, e.g., Lambic beers [57]. However, due to their abundance in HTC liquid byproducts for all different sorts of biomass, it is much more likely that majority of them were produced during HTC. On the other hand, their presence in the initial solution could have some influence on the results of the process, as the presence of HTC products in the liquid before performing hydrothermal carbonization typically influences the composition of the liquid. This was demonstrated by Stemann et al. [58] and M.T. Reza et al. [59]. Since some of the dominant compounds also happened to be dominant for the experiments conducted by Erdogan et al. for orange pomace [33], it seems to be sensible to hypothesize that the liquid byproduct could be a feasible feedstock for anaerobic digestion. This could be supported by the biogas yields obtained by Erdogan et al. [33]. On the other hand, the influence of 3-pyridinol and 2,3-butadienol on the process of anaerobic digestion is not well understood. Therefore, a suite of anaerobic digestion experiments seems to be in order to confirm this hypothesis. Alternatively, as suggested by some authors such as A. Shende et al. and Kumar et al., there is an existing potential for production of biocrude, bio-oil, and hydrogen using a catalytic process $[16,60,61]$. Another potentially interesting option would be performing the HTC process on spent grain as a first stage of production of pharmaceuticals, as 3-pyridinol has been detected as a thermal degradation product of Salvia divinorum [53]. This endemic Mexican plant is regarded as a natural remedy for depression [62-64]. However, this would not be straightforward due to the necessity to separate this compound from all the other compounds, including water.

\section{Conclusions}

Overall, hydrothermal carbonization of the spent grain seems to be beneficial when fuel properties are considered. An in-depth study is necessary in order to optimize the process for that particular feedstock. Taking the results of this preliminary study into consideration, it seems plausible to consider hydrochars made of spent grain suitable for combustion, gasification, and pyrolysis alike. In particular, results of the DTG analysis, along with significant decrease in $\mathrm{O} / \mathrm{C}$ ratio and decrease in the ash 
content, seem to indicate that this valorization technique makes the spent grain especially suitable for fast pyrolysis. More research is needed on de-watering, drying, and grindability of the hydrochars with respect to different temperatures and residence times of the HTC process. Biogas production using the HTC liquid byproduct, and hydrochars as additives enhancing the process, also seems to be a good topic of the future studies.

Author Contributions: Conceptualization can be attributed to L.N. and M.J.; investigation to M.W., M.J. and M.B.; data curation to K.K. and D.S.; writing-original draft preparation to L.N. and M.J.; writing-review and editing to L.N., M.J., A.T. and H.P.-K.; visualization to L.N. and M.J.; supervision to A.T. and H.P.-K.

Funding: Support of the statutory grant no. 0401/0208/18 is gratefully acknowledged.

Conflicts of Interest: The authors declare no conflict of interest.

\section{References}

1. Wiśniewski, P. Piwa Historie Niezwykke; Print Shops PREGO: Warszawa, Poland, 1993; ISBN 83-85830-00-6.

2. Valamoti, S.M. Brewing beer in wine country? First archaeobotanical indications for beer making in Early and Middle Bronze Age Greece. Veg. Hist. Archaeobot. 2018, 27, 611-625. [CrossRef]

3. Beer Production Worldwide from 1998 to 2017 (in Billion Hectoliters). Available online: https:/ /www. statista.com/statistics/270275/worldwide-beer-production/ (accessed on 21 December 2018).

4. Bentzen, J.; Smith, V. Structural Changes in the Consumption of Beer, Wine and Spirits in OECD Countries from 1961 to 2014. Beverages 2018, 4, 8. [CrossRef]

5. Lynch, K.M.; Steffen, E.J.; Arendt, E.K. Brewers' spent grain: A review with an emphasis on food and health. J. Inst. Brew. 2016, 122, 553-568. [CrossRef]

6. Stojceska, V.; Ainsworth, P. The effect of different enzymes on the quality of high-fibre enriched brewer's spent grain breads. Food Chem. 2008, 110, 865-872. [CrossRef] [PubMed]

7. Kreisz, S. Malting. In Handbook of Brewing Processes, Technology, Markets; Eßlinger, H.M., Ed.; WILEY-VCH: Weinheim, Germany, 2009; pp. 147-164. ISBN 978-3-527-31674-8.

8. Dylkowski, W. Technologia Browarnictwa; Wydawnictwo przemysłu lekkiego i spożywczego: Warszawa, Poland, 1963.

9. Sperandio, G.; Amoriello, T.; Carbone, K.; Fedrizzi, M.; Monteleone, A.; Tarangioli, S.; Pagano, M. Increasing the value of spent grain from craft microbreweries for energy purposes. Chem. Eng. Trans. 2017, 58, 487-492. [CrossRef]

10. Enweremadu, C.C.; Waheed, M.A.; Adekunle, A.A.; Adeala, A. The Energy Potential of Brewer's Spent Grain for Breweries in Nigeria. Eng. Appl. Sci. 2008, 3, 175-177.

11. Funke, A.; Ziegler, F. Hydrothermal carbonisation of biomass: A summary and discussion of chemical mechanisms for process engineering. Biofuels Bioprod. Biorefin. 2010, 4, 160-177. [CrossRef]

12. Moscicki, K.J.; Niedzwiecki, L.; Owczarek, P.; Wnukowski, M. Commoditization of wet and high ash biomass: Wet torrefaction-A review. J. Power Technol. 2017, 97, 354-369.

13. Reza, M.T.; Lynam, J.G.; Uddin, M.H.; Coronella, C.J. Hydrothermal carbonization: Fate of inorganics. Biomass Bioenergy 2013, 49, 86-94. [CrossRef]

14. Reza, M.T.; Andert, J.; Wirth, B.; Busch, D.; Pielert, J.; Lynam, J.G.; Mumme, J. Hydrothermal Carbonization of Biomass for Energy and Crop Production. Appl. Bioenergy 2014, 1, 11-29. [CrossRef]

15. Reza, M.T.; Yan, W.; Uddin, M.H.; Lynam, J.G.; Hoekman, S.K.; Coronella, C.J.; Vásquez, V.R. Reaction kinetics of hydrothermal carbonization of loblolly pine. Bioresour. Technol. 2013, 139, 161-169. [CrossRef] [PubMed]

16. Tungal, R.; Shende, R.V. Hydrothermal liquefaction of pinewood (Pinus ponderosa) for $\mathrm{H}_{2}$, biocrude and bio-oil generation. Appl. Energy 2014, 134, 401-412. [CrossRef]

17. Nan, W.; Shende, A.R.; Shannon, J.; Shende, R.V. Insight into Catalytic Hydrothermal Liquefaction of Cardboard for Biofuels Production. Energy Fuels 2016, 30, 4933-4944. [CrossRef]

18. Shende, R.; Tungal, R. Subcritical Aqueous Phase Reforming of Wastepaper for Biocrude and $\mathrm{H}_{2}$ Generation. Energy Fuels 2013, 27, 3194-3203. [CrossRef]

19. Funke, A.; Ziegler, F. Heat of reaction measurements for hydrothermal carbonization of biomass. Bioresour. Technol. 2011, 102, 7595-7598. [CrossRef] [PubMed] 
20. Acharjee, T.C.; Coronella, C.J.; Vasquez, V.R. Effect of thermal pretreatment on equilibrium moisture content of lignocellulosic biomass. Bioresour. Technol. 2011, 102, 4849-4854. [CrossRef] [PubMed]

21. Favas, G.; Jackson, W.R.; Marshall, M. Hydrothermal dewatering of lower rank coals. 3. High-concentration slurries from hydrothermally treated lower rank coals. Fuel 2003, 82, 71-79. [CrossRef]

22. Nakagawa, H.; Namba, A.; Böhlmann, M.; Miura, K. Hydrothermal dewatering of brown coal and catalytic hydrothermal gasification of the organic compounds dissolving in the water using a novel $\mathrm{Ni} /$ carbon catalyst. Fuel 2004, 83, 719-725. [CrossRef]

23. Favas, G.; Jackson, W.R. Hydrothermal dewatering of lower rank coals. 1: Effects of process conditions on the properties of dried product. Fuel 2003, 82, 53-57. [CrossRef]

24. Favas, G.; Jackson, W.R. Hydrothermal dewatering of lower rank coals. 2. Effects of coal characteristics for a range of Australian and international coals. Fuel 2003, 82, 59-69. [CrossRef]

25. Rao, Z.; Zhao, Y.; Huang, C.; Duan, C.; He, J. Recent developments in drying and dewatering for low rank coals. Prog. Energy Combust. Sci. 2015, 46, 1-11. [CrossRef]

26. Mursito, A.T.; Hirajima, T.; Sasaki, K. Upgrading and dewatering of raw tropical peat by hydrothermal treatment. Fuel 2010, 89, 635-641. [CrossRef]

27. Wnukowski, M.; Owczarek, P.; Niedźwiecki, Ł. Wet Torrefaction of Miscanthus - Characterization of Hydrochars in View of Handling, Storage and Combustion Properties. J. Ecol. Eng. 2015, 16, 161-167. [CrossRef]

28. Liu, Z.; Quek, A.; Balasubramanian, R. Preparation and characterization of fuel pellets from woody biomass, agro-residues and their corresponding hydrochars. Appl. Energy 2014, 113, 1315-1322. [CrossRef]

29. Volpe, M.; Wüst, D.; Merzari, F.; Lucian, M.; Andreottola, G.; Kruse, A.; Fiori, L. One stage olive mill waste streams valorisation via hydrothermal carbonisation. Waste Manag. 2018, 80, 224-234. [CrossRef] [PubMed]

30. Koppejan, J.; Sokhansanj, S.; Melin, S.; Madrali, S. Status Overview of Torrefaction Technologies; Bioenergy Task 32 report; International Energy Agency: Paris, France, 2015; ISBN 978-1-910154-23-6.

31. Ruiz, H.A.; Rodríguez-Jasso, R.M.; Fernandes, B.D.; Vicente, A.A.; Teixeira, J.A. Hydrothermal processing, as an alternative for upgrading agriculture residues and marine biomass according to the biorefinery concept: A review. Renew. Sustain. Energy Rev. 2013, 21, 35-51. [CrossRef]

32. Svensson, K.; Kjørlaug, O.; Higgins, M.J.; Linjordet, R.; Horn, S.J. Post-anaerobic digestion thermal hydrolysis of sewage sludge and food waste: Effect on methane yields, dewaterability and solids reduction. Water Res. 2018, 132, 158-166. [CrossRef]

33. Erdogan, E.; Atila, B.; Mumme, J.; Reza, M.T.; Toptas, A.; Elibol, M.; Yanik, J. Characterization of products from hydrothermal carbonization of orange pomace including anaerobic digestibility of process liquor. Bioresour. Technol. 2015, 196, 35-42. [CrossRef]

34. Funke, A.; Mumme, J.; Koon, M.; Diakité, M. Cascaded production of biogas and hydrochar from wheat straw: Energetic potential and recovery of carbon and plant nutrients. Biomass Bioenergy 2013, 58, 229-237. [CrossRef]

35. Wirth, B.; Mumme, J. Anaerobic Digestion of Waste Water from Hydrothermal Carbonization of Corn Silage. Appl. Bioenergy 2014, 1, 1-10. [CrossRef]

36. Luz, F.C.; Cordiner, S.; Manni, A.; Mulone, V.; Rocco, V. Anaerobic digestion of coffee grounds soluble fraction at laboratory scale: Evaluation of the biomethane potential. Appl. Energy 2017, 207, 166-175. [CrossRef]

37. Fagbohungbe, M.O.; Herbert, B.M.J.; Hurst, L.; Ibeto, C.N.; Li, H.; Usmani, S.Q.; Semple, K.T. The challenges of anaerobic digestion and the role of biochar in optimizing anaerobic digestion. Waste Manag. 2017, 61, 236-249. [CrossRef] [PubMed]

38. Codignole Luz, F.; Cordiner, S.; Manni, A.; Mulone, V.; Rocco, V. Biochar characteristics and early applications in anaerobic digestion-A review. J. Environ. Chem. Eng. 2018, 6, 2892-2909. [CrossRef]

39. Zhou, Y.; Engler, N.; Nelles, M. Symbiotic relationship between hydrothermal carbonization technology and anaerobic digestion for food waste in China. Bioresour. Technol. 2018, 260, 404-412. [CrossRef] [PubMed]

40. Xu, J.; Mustafa, A.M.; Lin, H.; Choe, U.Y.; Sheng, K. Effect of hydrochar on anaerobic digestion of dead pig carcass after hydrothermal pretreatment. Waste Manag. 2018, 78, 849-856. [CrossRef]

41. Codignole Luz, F.; Volpe, M.; Fiori, L.; Manni, A.; Cordiner, S.; Mulone, V.; Rocco, V. Spent coffee enhanced biomethane potential via an integrated hydrothermal carbonization-anaerobic digestion process. Bioresour. Technol. 2018, 256, 102-109. [CrossRef] 
42. Wilk, M.; Magdziarz, A. Hydrothermal carbonization, torrefaction and slow pyrolysis of Miscanthus giganteus. Energy 2017, 140, 1292-1304. [CrossRef]

43. Gao, L.; Volpe, M.; Lucian, M.; Fiori, L.; Goldfarb, J.L. Does Hydrothermal Carbonization as a Biomass Pretreatment Reduce Fuel Segregatuin of Coal-Biomass Blends During Oxidation? Energy Convers. Manag. 2018, 93-104. [CrossRef]

44. Pearce, I.; Culbert, J.; Cass, D.; Cozzolino, D.; Wilkinson, K. Influence of Sample Storage on the Composition of Carbonated Beverages by MIR Spectroscopy. Beverages 2016, 2, 26. [CrossRef]

45. Yan, W.; Hastings, J.T.; Acharjee, T.C.; Coronella, C.J.; Vásquez, V.R. Mass and energy balances of wet torrefaction of lignocellulosic biomass. Energy Fuels 2010, 24, 4738-4742. [CrossRef]

46. Phyliss2 Database. Available online: https://phyllis.nl/Home/Help (accessed on 24 December 2018).

47. Pawlak-Kruczek, H.; Krochmalny, K.; Mościcki, K.; Zgóra, J.; Czerep, M.; Ostrycharczyk, M.; Niedźwiecki, Ł. Torrefaction of Various Types of Biomass in Laboratory Scale, Batch-Wise Isothermal Rotary Reactor and Pilot Scale, Continuous Multi-Stage Tape Reactor. Eng. Prot. Environ. 2017, 20, 457-472. [CrossRef]

48. Weber, K.; Heuer, S.; Quicker, P.; Li, T.; Løvås, T.; Scherer, V. An Alternative Approach for the Estimation of Biochar Yields. Energy Fuels 2018. [CrossRef]

49. Moscicki, K.J.; Niedzwiecki, L.; Owczarek, P.; Wnukowski, M. Commoditization of biomass: Dry torrefaction and pelletization-A review. J. Power Technol. 2014, 94, 233-249.

50. Pawlak-Kruczek, H.; Krochmalny, K.K.; Wnukowski, M.; Niedzwiecki, L. Slow pyrolysis of the sewage sludge with additives: Calcium oxide and lignite. J. Energy Resour. Technol. 2018, 140. [CrossRef]

51. Poudel, J.; Karki, S.; Gu, J.H.; Lim, Y.; Oh, S.C. Effect of Co-Torrefaction on the Properties of Sewage Sludge and Waste Wood to Enhance Solid Fuel Qualities. J. Residuals Sci. Technol. 2017, 14, 23-36. [CrossRef]

52. Pulka, J.; Wiśniewski, D.; Gołaszewski, J.; Białowiec, A. Is the biochar produced from sewage sludge a good quality solid fuel? Arch. Environ. Prot. 2016, 42, 125-134. [CrossRef]

53. Royal Society of Chemistry ChemSpider I Search and Share Chemistry. Available online: http://www. chemspider.com/ (accessed on 23 November 2018).

54. Bridgwater, A.V. Review of fast pyrolysis of biomass and product upgrading. Biomass Bioenergy 2012, 38, 68-94. [CrossRef]

55. Louwes, A.C.; Basile, L.; Yukananto, R.; Bhagwandas, J.C.; Bramer, E.A.; Brem, G. Torrefied biomass as feed for fast pyrolysis: An experimental study and chain analysis. Biomass Bioenergy 2017, 105, 116-126. [CrossRef]

56. Prins, M.J.; Ptasinski, K.J.; Janssen, F.J.J.G. More efficient biomass gasification via torrefaction. Energy 2006, 31, 3458-3470. [CrossRef]

57. Thompson Witrick, K.; Duncan, S.; Hurley, K.; O'Keefe, S. Acid and Volatiles of Commercially-Available Lambic Beers. Beverages 2017, 3, 51. [CrossRef]

58. Stemann, J.; Putschew, A.; Ziegler, F. Hydrothermal carbonization: Process water characterization and effects of water recirculation. Bioresour. Technol. 2013, 143, 139-146. [CrossRef] [PubMed]

59. Reza, M.T.; Rottler, E.; Herklotz, L.; Wirth, B. Hydrothermal carbonization (HTC) of wheat straw: Influence of feedwater $\mathrm{pH}$ prepared by acetic acid and potassium hydroxide. Bioresour. Technol. 2015, 182, 336-344. [CrossRef] [PubMed]

60. Kumar, S.; Bhalla, A.; Shende, R.V.; Sani, R.K. Decentralized thermophilic biohydrogen: A more efficient and cost-effective process. BioResources 2012, 7, 1-2.

61. Kumar, S.; Gupta, R.B. Biocrude production from switchgrass using subcritical water. Energy Fuels 2009, 23, 5151-5159. [CrossRef]

62. Braida, D.; Capurro, V.; Zani, A.; Rubino, T.; Viganò, D.; Parolaro, D.; Sala, M. Potential anxiolytic- And antidepressant-like effects of salvinorin A, the main active ingredient of Salvia divinorum, in rodents. Br. J. Pharmacol. 2009, 157, 844-853. [CrossRef] [PubMed]

63. Hanes, K.R. Antidepressant effects of the herb Salvia divinorum: A case report. J. Clin. Psychopharmacol. 2001, 21, 634-635. [CrossRef] [PubMed]

64. Hanes, K. Salvia divinorum: Clinical and Research Potential. Maps 2003, XIII, 18-20.

(C) 2019 by the authors. Licensee MDPI, Basel, Switzerland. This article is an open access article distributed under the terms and conditions of the Creative Commons Attribution (CC BY) license (http://creativecommons.org/licenses/by/4.0/). 